\title{
THE TECHNOLOGY OF RECEIVING AND DRYING OF A FOOD CASEIN
}

\author{
Skrypnichenko Dmitriy ${ }^{1}$ \\ Lanzhenko Liubov ${ }^{2}$
}

DOI: https://doi.org/10.30525/978-9934-571-89-3_119

The problem of a full and rational use of milk exists in the whole world despite the system of economic relations and production volumes. This problem has a significant environmental component. Its essence exists in the traditional technology of a dairy production. With a milk separating and a butter production a secondary product appears, which is skim milk. When producing 1 tone of butter up to 20 tone of skim milk is obtained, however its amount depends on the mass fraction of fat in the final product. And the main product of this skimmed milk is casein [1, p. 60].

Due to its composition and qualities a food casein is used in dairy, meat and confectionery enterprises as a protein filler, which improves the quality of final products.

Today the largest manufacturers of a casein are New Zealand, Australia, Argentina and France. They cover $90 \%$ of the world production and export in this sphere.

According to the fact that there is a lot of casein which does not meet the requirements of ND quality indicators at the market, an urgent need of a quality food casein does exist. And a quality of casein depends on a proper technological process. The quality of a food casein can be improved mainly at all stages of its production [2, p. 21].

One of the main and important factors that influences the quality of a casein is the drying process, therefore the main purpose of this work is to study the effects of this drying process of a food casein in order to receive a high quality product.

To receive a food casein skim milk is turned into a clot with the addition of: acid; bacterial fermentation; serum, which is fermented with bacterial liver; milkcoagulation milk enzymes.

When receiving protein concentrates, namely casein, casein fractions of milk proteins are transferred from skimmed milk into the final product.

Food casein was received with the traditional technological schemes that differ from each other with a type of coagulant and affect the yield of a casein and its qualitative indices.

\footnotetext{
${ }^{1}$ Odesa National Academy of Food Technologies, Ukraine

${ }^{2}$ Odesa National Academy of Food Technologies, Ukraine
} 
When receiving a food casein - sample $\mathbf{1}$ - an acidic serum with a titrated acidity of $160^{\circ} \mathrm{T}$ was added in the role of a coagulant into skimmed milk at a temperature of 30-35 ${ }^{0} \mathrm{C}$. Previously a serum was sourced with a combination of fermentations FD DVS CHN-19 + FD DVS Flora Danica by the company Christian Hansen. These fermentations contain the mixed cultures Lactococcus lactis ssp. lactis, lactococcus lactis ssp. cremoris, Leuconostoc mesenteroides ssp. cremoris, Lactococcus lactis ssp. diacetylactis.

When receiving a food casein - sample 2 - a combination of ferments FD DVS CHN-19 + FD DVS Flora Danica was added in the role of a coagulant into skimmed milk at a temperature of $30-35^{\circ} \mathrm{C}$.

When receiving a food casein - sample 3 - a milk-enzyme ferment CHY-MAX Extra $600 \mathrm{IMCU}$ was added in the role of a coagulant into skimmed milk at a temperature of $30-32{ }^{\circ} \mathrm{C}$.

When receiving a food casein - sample 4 - a laboratory leaven "Symbiter concentrated" was added in the role of a coagulant into skimmed milk at a temperature of $30-35{ }^{\circ} \mathrm{C}$. That was $4 \%$ of a milk volume and composed of Bifidobacterium, Lactobacillus, Propionibacterium, Lactococcus, a number of strains in the probiotic is 14 , the concentration of cells is $10^{12}$, CFU/dose.

After coagulation a leaven was removed from all samples, casein flakes were washed with pasteurized and cooled water for 3 times per 10 minutes. The next operation was to squeeze the grain to a moisture content of $150-170 \%$ and to a granulate casein. The final operation was a drying process in a hanging ball and in a fixed ball.

The received clots have different structures, which are shown in table 1.

Table 1

The characteristics of the received clots

\begin{tabular}{|l|c|}
\hline Sample (type of coagulant) & Consistency of a clot \\
\hline Sample1 (sour serum) & flakes in serum \\
\hline $\begin{array}{l}\text { Sample 2 (combination of fermentations } \\
\text { FD DVS CHN-19 + FD DVS Flora Danica) }\end{array}$ & loose and granular \\
\hline $\begin{array}{l}\text { Sample 3 (milk enzymes CHY-MAX Extra } \\
\text { 600 IMCU) }\end{array}$ & gum-like \\
\hline Sample 4 (leaven "Symbiter") & loose and granular \\
\hline
\end{tabular}

The received consistency of clots is substantiated by the following. The acid coagulation occurs in samples 1,2 and 4 . The 1 sample has a true coagulation that is a result of a rapid $\mathrm{pH}$ decrease of skimmed milk from $6,6 \ldots 6,8$ to $4,7 \ldots 4,6$. A precipitate of casein was formed. The mechanism of a true coagulation lays in a reduction of the negative charge which is caused by the carboxyl groups of monoaminodicarboxylic acids (aspartic and glutamine) and by the leftovers of 
phosphoric acid with hydrogen ions of serum (lactic acid is formed). A stronger lactic acid cleaves calcium from calcium phosphate, which binds the submicles of casein to the micelle, resulting in breaking down of micelles into submicles, that is a precipitate is finely dispersed [3, p. 33].

The mechanism of a clot's formation is still the same while a casein is allocated in 2-nd and 4-th samples. Only the formation of a precipitate (as in the 1-st sample) does not occur, but a gel is formed, the structure of which is submicceloric.

In the 4-th sample a rennet coagulation has its place. With a milk-enzyme ferment the $\chi$-casein, which occupies $50 \%$ of the surface of the casein micelle, breaks down between 105 and 106 aminoacids to para-kappa-casein and glycemacropeptide. This latter one has a high charge and a hydrophilicity. With its detachment the zeta potential (charge) is reduced by almost twice on a surface. As a result of a charge reduction the micelles are combined, because the attraction forces begin to prevail over the repulsion forces. A gel composed of micelles is formed, that is, an emitted casein has a different degree of dispersion [3, p. 55].

In 1, 2, 4 samples the gel is finely dispersed and the particles have a size of $10 \ldots 15 \mathrm{~nm}$. In the $3 \mathrm{~d}$ sample a particles' size is up to $400 \mathrm{~nm}$.

A comparative description of the ways of a casein drying is shown in table 2.

A duration of a casein drying process in a hanging ball and in a fixed ball (specific load of material $60 \mathrm{~kg} / \mathrm{m} 2$, drying rate $5 \mathrm{~m} / \mathrm{s}$, wbeg $=170 \%$, wend $=4 \%$ ) at a temperature of a drying agent, ${ }^{\circ} \mathrm{C}$

\begin{tabular}{|l|c|c|c|c|c|c|c|c|c|c|c|c|}
\hline \multirow{2}{*}{$\begin{array}{l}\text { Sample } \\
\text { (type of coagulant) }\end{array}$} & \multicolumn{9}{|c|}{ hanging ball } & \multicolumn{6}{c|}{ fixed ball } \\
\cline { 2 - 13 } & 70 & 80 & 90 & 100 & 110 & 120 & 70 & 80 & 90 & 100 & 110 & 120 \\
\hline $\begin{array}{l}\text { Sample 1 } \\
\text { (sour serum) }\end{array}$ & 147 & 102 & 64 & 50 & 42 & 34 & 152 & 117 & 72 & 59 & 48 & 41 \\
\hline $\begin{array}{l}\text { Samole 2 } \\
\text { (combination of } \\
\text { fermentations FD DVS } \\
\text { CHN-19 + FD DVS Flora } \\
\text { Danica) }\end{array}$ & 140 & 90 & 55 & 44 & 35 & 28 & 146 & 98 & 66 & 52 & 43 & 34 \\
\hline $\begin{array}{l}\text { Sample 3 (milk enzymes } \\
\text { CHY-MAX Extra 600 } \\
\text { IMCU) }\end{array}$ & 149 & 111 & 68 & 53 & 44 & 36 & 154 & 120 & 74 & 62 & 51 & 45 \\
\hline $\begin{array}{l}\text { Sample 4 (leaven } \\
\text { "Symbiter") }\end{array}$ & 145 & 96 & 61 & 47 & 39 & 32 & 150 & 114 & 70 & 57 & 46 & 39 \\
\hline
\end{tabular}

As it follows from the table 2 the duration of a casein drying process is lower in a hanging ball if compared with a fixed ball. This is explained by the fact that the drying in a hanging ball is characterized by a continuous chaotic motion and a particles' mixing in a certain volume in height and by a highly developed surface of a 
material's touch with a heated air. With such a drying process each particle is evenly washed by a stream of a heated air from all sides. It leads to a steady heating of the material which allows to use an increased temperature of the drying agent (above $100{ }^{\circ} \mathrm{C}$ ) and an increased material load. This also gives a significant reduction in time, a decrease of a heat impact on the product, a better preservation of the product's qualities if compared with a fixed ball.

A casein that is received with schemes 2 and 4 is being dried faster than a casein that is received with other schemes both in hanging and fixed balls. This is due to the samples 2 and 4 that have a loose and granular structure (finely dispersed composition - the particles have a size of $10 \ldots 12 \mathrm{~nm}$ ).

A casein that is received with scheme 4 allows to shorten a fermentation's duration of skimmed milk by a leaven "Symbiter concentrated" if compared with a casein that is received with scheme 2 (from 8-12 hours to 4-6 hours). Also, the duration of pressing and drying of casein grains is reduced due to its high degree of dehydration at a temperature of $40-48^{\circ} \mathrm{C}$ for up to 30 minutes.

A casein that is received with scheme 3 (rennet) has a gum-like structure (particles' size up to $400 \mathrm{~nm}$ ), which makes it more difficult to dry.

According to the studies' results, the drying time of a casein in a hanging ball is reduced by 1.5 times if compared with a fixed ball and takes 30 minutes at a drying temperature of $100{ }^{\circ} \mathrm{C}$ to a final moisture content of $10 \%$.

\section{References:}

1. Bohosian M. V. (2010). Pishchevoi i tekhnycheskyi kazein: sposoby ispolzovaniia, sb. st. ekonomicheskie nauki, vol. 3, pp. 59-62.

2. Nedobiichuk T.V. (2003). Razrabotka tekhnolohii sushki tvoroha vo vzveshennom sloe. Dis. kand. tekhn. nauk: 05.18.04. Odessa, 2003.

3. Nechaev A.P., Traubenberh S.E., Kochetkova A.A. (2007). Pishchevaia khimiia, vol. 4, S.Pb.: HIORD. 